\title{
PERLINDUNGAN INVESTOR OBLIGASI DI PASAR MODAL MELALUI PENDEKATAN ETIKA BISNIS BAGI PENERBIT OBLIGASI
}

\section{Eduardus Bayo Sili}

\author{
* Dosen Fakultas Hukum Universitas Mataram, NTB \\ Korespondensi: eduardbayosili@yahoo.co.id \\ Naskah dikirim: 16 Maret 2016 \\ Naskah diterima untuk diterbitkan: 20 April 2016
}

\begin{abstract}
The success of a company in the business law perspective, it is not enough only measured by financial results and increase shareholder value (share holders value) merely, but people began to associate to how well the company has been applying the principles of good corporate governance. One of the forms of this principle of good corporate governance is the application of business ethics. Consistency of application of business ethics in the form of good corporate governance for the issuer (issuer) in managing the company, will no longer be just a merely appeal, but has become an ethical duty to be obeyed.
\end{abstract}

Keywords: business ethics, ethical obligations, the investor protection

\begin{abstract}
Abstrak
Keberhasilan suatu perusahaan dalam perspektif hukum bisnis, tidak cukup hanya diukur dari hasil kinerja keuangan dan peningkatan nilai pemegang saham (share holders value) semata, akan tetapi orang mulai mengaitkannya dengan seberapa baik perusahaan telah menerapkan prinsip good corporate governance. Salah satu wujud dari prinsip good corporate governance ini adalah penerapan etika bisnis. Konsistensi penerapan etika bisnis dalam wujud good corporate governance bagi penerbit obligasi (emiten) dalam mengelola perusahaannya, tidak lagi menjadi hanya sekedar himbauan semata, tetapi sudah menjadi kewajiban etis yang harus diataati.
\end{abstract}

Kata kunci: etika bisnis, kewajiban etis, perlindungan investor

\section{Pendahuluan}

Perlindungan investor menjadi isu yang sangat penting dalam pengembangan sektor keuangan, termasuk pasar modal. Perlindungan investor menjadi begitu krusial karena seringkali terjadi eksploitasi oleh insiders (pengendali dan pihak manajemen atau direksi) perusahaan terhadap outside investors (pemegang saham publik dan kreditor). Eksploitasi yang dilakukan 
pihak insiders ini bertujuan untuk mengambil resources yang ada di perusahaan bagi kepentingan ekonomis pribadi insiders dengan cost yang ditanggung oleh outside investors. Eksploitasi ini dapat berupa penjualan aset, output, maupun saham perusahaan kepada pihak-pihak yang terafiliasi dengan insiders dengan nilai penjualan di bawah harga pasar. ${ }^{1}$

Krisis finansial yang melanda Asia di tahun 1997-1998 dan beberapa kasus gagal bayar baik pada periode tersebut ${ }^{2}$ maupun kasus gagal bayar pada periode di tahun 2013-2015 disinyalir sebagai akibat lemahnya praktik good corporate governance. ${ }^{3}$ Salah satu aspek dari good corporate governance tersebut adalah etika bisnis. Tulisan ini hendak mengelaborasi obligasi dan investasi di pasar modal dan pentingnya penerapan etika bisnis bagi penerbit obligasi (emiten) sebagai bentuk pertanggungjawaban etis dalam mengelola perusahaannya berdasarkan prinsip pengelolaan perusahaan yang baik (good corporate governance).

\section{Obligasi dan Investasi di Pasar Modal}

Salah satu faktor penting dalam menentukan berhasilnya pembangunan adalah pengembangan dunia usaha atau investasi. Investasi dalam jumlah yang sangat besar sangat diperlukan untuk pembiayaan pembangunan. Tanpa kehadiran investor, rasanya sangat sulit bagi Indonesia untuk dapat maju sejajar dengan negara-negara lain di kawasan ASEAN khususnya dan dunia pada umumnya. ${ }^{4}$ Pembangunan ekonomi nasional harus ditopang oleh investasi, baik investasi yang dilaksanakan oleh pemerintah maupun swasta.

Pasar modal memiliki peran yang startegis dalam investasi karena pasar modal menjalankan dua fungsi sekaligus, yaitu fungsi ekonomi dan fungsi keuangan. ${ }^{5}$ Memiliki fungsi ekonomi karena pasar modal menyediakan fasilitas atau wahana untuk mempertemukan dua kepentingan yaitu pihak yang memiliki kelebihan dana (investor) dan pihak yang memerlukan dana (issuer). Investor dapat menginvestasikan dana tersebut dengan harapan memperoleh imbalan sedangkan issuer dapat memanfaatkan dana tersebut untuk kepentingan investasi. Memiliki fungsi keuangan karena pasar modal memberikan kemungkinan dan kesempatan memperoleh imbalan bagi pemilik dana sesuai dengan karakteristik investasi yang dipilih. ${ }^{6}$

1 Indra Surya dan Ivan Yustiavandana, "Penerapan Good Corporate Governance Mengesampaingkan Hak-Hak Istimewa Demi Kelangsungan Usaha, (Jakarta: Kencana, Jakarta, 2008), hal. 43.

2 I Nyoman Tjager, et al., "Corporate Governance: Tantangan dan Kesempatan bagi Komunitas Bisnis Indonesia”, (Jakarta: Prenhallindo, 2003), hal. 22.

${ }^{3}$ Eduardus Bayo Sili, Prinsip Perlindungan Hukum Investor Obligasi, Disertasi, Program Studi Doktor Ilmu Hukum Universitas Airlangga, Surabaya, 2015. hal. 16.

${ }^{4}$ Ibid., hal. 1.

5 Tjiptono Darmadji dan Hendy Fakhruddin, "Pasar Modal di Indonesia", (Jakarta: Salemba Empat, 2001), hal. 2.

${ }^{6}$ Ibid. 
Mewujudkan perekonomian negara yang kuat secara makro atau lebih tepatnya ketahanan ekonomi, pasar modal menjadi pilihan yang strategis karena pasar modal tidak hanya bermanfaat bagi investor dan issuer semata, akan tetapi menjadi tulang punggung perekonomian negara. Sebagai tulang punggung ekonomi negara, pasar modal dengan demikian, menjadi indikator kemajuan perekonomian suatu negara serta menunjang perkembangan ekonomi negara yang bersangkutan. Berputar-nya roda perekonomian suatu negara, sumber dana bagi pembiayaan-pembiayaan beroperasinya perusahaanperusahaan yang merupakan tulang ekonomi suatu negara sangat terbatas, maka perlu dicarikan solusi pembiayaan yang bersifat jangka panjang. Pasar modal muncul sebagai solusi pembiayaan jangka panjang. Melalui dukungan dana jangka panjang ini, roda pembangunan khususnya di bidang swasta dapat berjalan sesuai dengan yang direncanakan. ${ }^{7}$

Sebagai salah satu produk investasi di pasar modal, obligasi mengalami perkembangan yang cukup pesat sejak tahun $2000 .{ }^{8}$ Hal ini diawali dengan penerbitan obligasi pemerintah RI yang berkaitan dengan program penyelamatan industri perbankan yang mengalami rush, sehingga perlu diselamatkan kondisi likuiditas keuangannya. Nilai obligasi pemerintah mencapai angka tertinggi sebesar Rp 1.016,524 triliun. Nilai tersebut terdiri dari: (a) Rp 9,970 triliun dalam bentuk surat utang (obligasi) dalam rangka kredit program; (b) Rp 293,911 triliun dalam bentuk obligasi penjaminan; ${ }^{9}$ (c) Rp 713,025 triliun dalam bentuk obligasi rekapitalisasi yang disuntikan ke bank-bank pemerintah dan swasta yang sahamnya telah diambil alih pemerintah. ${ }^{10}$ Ada tiga jenis obligasi rekapitalisasi, yakni obligasi berbunga mengambang (variable rate bon/), ${ }^{11}$ obligasi berbunga tetap (fixed-rate bond) ${ }^{12}$ dan obligasi lindung nilai (hedged bond). ${ }^{13}$

${ }^{7}$ Robert Ang, "Buku Pintar Pasar Modal Indonesia, (Jakarta: Mediasoft Indonesia, 1997), hal. 32.

${ }^{8}$ Sapto Rahardjo, "Panduan Investasi Obligasi”, (Jakarta: Gramedia Pustaka Utama, 2003), hal. 1.

${ }^{9}$ Obligasi penjaminan diterbitkan pemerintah untuk diserahkan ke Bank Indonesia guna menutup kewajiban pemerintah karena telah memerintahkan bank sentral tersebut menyalurkan Bantuan Likuiditas BI (BLBI) ke bank-bank yang menghadapi kesulitan likuiditas selama krisis moneter. BLBI tersebut adalah utang komersial yang harus dibayar kembali oleh penerima. Hal ini berarti bahwa obligasi penjaminan diterbitkan untuk mengambil alih hak tagih atas BLBI yang telah disalurkan ke bank-bank. Tagihan ini kemudian dikelola oleh Badan Penyehatan Perbankan Nasional (BPPN). Ketika bank penerima BLBI tidak mampu membayar kembali, maka tagihan atas BLBI tersebut kemudian dikonversi menjadi penyertaan sementara (PMS).

10 Jaka E. Cahyana, "Langkah Taktis Metodis Berinvestasi di Obligasi", (Jakarta: Elex Media Komputindo, 2004), hal. 1-2.

${ }^{11}$ Obligasi ini membayar bunga setiap 3 bulan yang besarnya sama dengan bunga diskonto SBI 3 bulan. Obligasi ini terdiri dari 6 seri dengan tenor antara 3 samapi 10 tahun dan dibukukan di bank penerima sebagai komponnen modal sehingga nilai rasio kecukupan modal (capital adecuacy ratio/CAR) mencapai nol persen. Ibid., hal. 2.

12 Obligasi jenis ini memiliki suku bunga tetap sampai jatuh tempo dan diterbitkan untuk menaikkan CAR bank-bank penerima sehingga mencapai $4 \%$ seperti disyaratkan oleh bank sentral. Obligasi ini mempunyai masa jatuh tempo paling lama 15 tahun. Kupon dibayarkan setiap 6 bulan. Ibid., hal. 3 .

${ }^{13}$ Obligasi yang kuponnya dikatkan dengan tingkat suku bunga SIBOR (Singapore Interbank Offered Rate) 3 bulan ditambah premi $2 \%$ dari pokok obligasi yang diindeks dengan perubahan kurs 
Meskipun nilai kredit perbankan di Indonesia jauh lebih besar dibandingkan dengan nilai kapitalisasi saham dan obligasi, namun ada kalanya lembaga perbankan tidak mampu memberikan kredit kepada masyarakat peminjam (debitor) karena jumlah dana yang disediakan oleh bank tidak cukup tersedia. Jumlah kebutuhan dana sedemikian besar sehingga tidak ada satu atau beberapa bank yang mampu memenuhi kebutuhannya. Hal ini pernah terjadi pada pertengahan 1997, saat krisis yang melanda Indonesia dimana perbankan tidak bisa menyalurkan kredit karena persoalan internal perbankan karena kredit macet dan persoalan eksternal seperti iklim bisnis yang tidak menguntungkan dan rendahnya kelaikan kredit perusahaan. ${ }^{14}$

Pertimbangan lainnya bagi emiten dalam menerbitkan obligasi adalah menyesuaikan dengan kebutuhan dana. Jika perusahaan membutuhkan dana untuk membangun pabrik yang baru akan berproduksi pada 10 tahun ke depan maka menghimpun dana melalui penerbitkan obligasi adalah sarana yang lebih cocok bagi perusahaan jika dibandingkan dengan melakukan pinjaman di bank. Secara ekonomis, biaya menerbitkan obligasi lebih murah dari pada biaya memperoleh pinjaman di bank. Pada awal tahun 2003 perusahaan (emiten) seakan berlomba menerbitkan obligasi. Selain karena dana perbankan belum banyak tersedia, pada waktu itu menerbitkan obligasi lebih murah dibandingkan dengan meminjam di bank. Sebagai ilustrasi, biaya menerbitkan obligasi sekitar $3 \%$ termasuk biaya pemeringkatan sekitar $0,05 \%$ dan biaya penjaminan sekitar 2,5\%. Menawarkan kupon bunga $4 \%$ dan $5 \%$ di atas suku bunga tolok ukur, yakni bunga diskonto Sertifikat Bank Indonesia (SBI), masih lebih murah bagi perusahaan menerbitkan obligasi daripada meminjam ke bank yang memungut bunga kredit antara $8 \%$ dan $9 \%$ di atas bunga SBI. ${ }^{15}$

Besarnya minat investasi pada obligasi berlandaskan tiga alasan yakni: pertama, penerbitan obligasi lebih mudah dan fleksibel jika dibandingkan dengan melakukan peminjaman di bank. Kedua, tingkat suku bunga obligasi bisa dibuat lebih menguntungkan bagi perusahaan (emiten) dibandingkan tingkat suku bunga pinjaman di bank yang cenderung meningkat. Ketiga, dalam melakukan pembelian obligasi, investor di pasar modal bisa mendapat keuntungan berupa tingkat suku bunga (kupon) dan mendapat kenaikan nilai nominal obligasi ke harga premium di pasar sekunder. ${ }^{16}$

Berdasarkan sudut pandang investor, obligasi adalah suatu instrumen investasi ${ }^{17}$ yang cukup menarik karena obligasi merupakan hutang piutang

rupiah terhadap dolar Amerika Serikat. Obligasi ini dimaksudkan untuk menutup posisi devisa neto (net open position) bank-bank yang direkapitalisasi. Ibid.

${ }^{14}$ Jaka E. Cahyana, Op. Cit., h. 97-98.

15 Ibid., hal. 98-99.

${ }^{16}$ Sapto Rahardjo, Op. Cit., hal. 2.

17 Tindakan investasi adalah tindakan yang dilakukan setelah melalui proses analisis dan memahami permasalahan investasi secara utuh, mengapa harus investasi, apa resikonya, bagaimana tatacaranya dan selanjutnya bagaimana melakukan pilihan investasi. Dengan demikian suatu tindakan investasi adalah tindakan yang dilakukan setelah melalui proses dan investasi itu menjanjikan adanya keamanan nilai pokok investasi dan hasil investasi yang memuaskan. Tindakan-tindakan yang tidak memenuhi persyaratan tersebut adalah tindakan spekulasi atau gambling. Lihat Nindyo Pramono, 
yang menimbulkan kewajiban dari emiten untuk membayar pokok dan bunga sebagaimana diperjanjikan. Pemegang obligasi memiliki suatu kepastian mengenai kapan dan berapa lama investasinya akan kembali. Hal tersebut sangat berbeda apabila dibandingkan dengan investasi dalam bentuk ekuitas yang keuntungan diperoleh dari dividen yang dibayarkan oleh perusahaan yang jumlahnya tidak pasti serta dari selisih harga beli dan harga jual saham ketika saham tersebut dijual. Sifat obligasi yang menawarkan kepada para investor hasil yang tetap dari investasinya sesuai yang diperjanjikan, membuat risiko memiliki sebuah obligasi itu lebih kecil dibandingkan saham.

Meskipun risiko investasi saham lebih besar dari obligasi, namun obligasi sebagai suatu instrumen hutang yang mengandalkan keuntungan dari pembayaran kembali oleh debitur/emiten bukanlah tanpa risiko. Risiko yang paling besar bagi pemegang obligasi adalah berhentinya pembayaran pokok dan bunga dari emiten atau debitur. Risiko usaha maupun penyimpangan penggunaan dana yang pada akhirnya menyebabkan default yang berakibat terjadinya wanprestasi dalam pembayaran kembali pokok dan bunga obligasi. Risiko penyimpangan penggunaan dana, lemahnya pengawasan dari otoritas yang berwewenang, terafiliasinya wali amanat dengan emiten, regulasi yang belum lengkap dan terabaikannya prinsip pengelolaan perusahaan yang baik oleh emiten merupakan faktor-faktor yang mempengaruhi perlindungan hukum investor obligasi.

\section{Etika Bisnis}

Etika berasal dari kata Yunani ethos, yang dalam bentuk jamaknya ta etha berarti adat istiadat atau kebiasaan. ${ }^{18}$ Etika dalam konteks benar dan salah sering dipadankan dengan moralitas. Thomas Morawetz menulis, kata "moralitas" (moral) berasal dari kata Latin mores berarti "customs" atau "conventional practices". ${ }^{19}$ Secara harfiah, memang pengertian moralitas justru persis sama dengan etika, yakni keduanya berkaitan dengan adat kebiasaan yang baik dalam masyarakat, akan tetapi etika dalam pengertian yang luas, tidak hanya mencakup moralitas namun juga mencakup filsafat moral yakni ilmu yang mengkaji tentang nilai dan norma etis yang berasal dari adat kebiasaan dalam masyarakat yang bersangkutan. Berkaitan dengan itu, Morawetz menyatakan:

In this sense, which very different from the sense in which we have been using the term morality, moral reasons are different from political reason, economic reason, and so on. In this view, whether

\footnotetext{
"Hukum PT. Go Public dan Pasar Modal", (Yogyakarta: Andi, 2013), hal. 2-3. Lihat juga Sumantoro, "Pengantar Tentang Pasar Modal di Indonesia", (Jakarta: Ghalia Indonesia, 1990), hal. 14.

${ }^{18}$ A. Sony Keraf, "Etika Bisnis; Tuntutan dan Relevansinya", (Yogyakarta: Kanisius, 1998), hal. 14.

19 Thomas Morawetz, "The Philosophy of Law: An Introduction", (New York: Macmillan Publishing, 1980), hal. 125-126.
} 
a reason is a moral reason depends on its subject matter. In the technical utilitarian sense, economic and political reason that refer to economic benefit and social benefits are themselves moral reasons. $^{20}$

Berdasarkan perspektif ilmu hukum, pengertian bisnis masuk dalam domain ilmu hukum dagang, yang dahulu diterjemahkan sebagai hukum bagi para pedagang. Siapa yang disebut sebagai pedagang? Menurut Volmar, sebagaimana dikutip oleh Nindyo Pramono ${ }^{21}$ menyebutkan bahwa pedagang adalah "die daden van koophandel uitoefende en daarvan zijn gewoon beroep maakte" (pedagang adalah orang yang menjalankan perbuatan perniagaan (daden van koophandel). Perbuatan perniagaan adalah perbuatan membeli barang untuk dijual lagi. Jika pengertian ini diikuti, agen perusahaan, supplier, konsinyasi, dan sebagainya tidak termasuk kedalam kualifikasi pedagang. Itulah sebabnya istilah pedagang di dalam Pasal 2-5 Wetboek van Koophandel diganti dengan istilah bedrift atau pengusaha. Jadi, pedagang dalam pengertian sekarang menurut terminologi hukum dagang adalah orang yang menjalankan perusahaan. ${ }^{22}$ Perusahaan adalah setiap bentuk usaha yang melakukan kegiatan secara tetap dan terus menerus dengan tujuan memperoleh keuntungan atau laba, baik yang diselenggarakan oleh orang-perorangan maupun badan usaha yang berbentuk badan hukum atau bukan badan hukum, yang didirikan dan berkedudukan dalam wilayah negara Republik Indonesia. ${ }^{23}$

Menurut Erry Riana Hardjapamekas, sebagaimana dikutip Paripurna P. Sugarda, ${ }^{24}$ menyebutkan bahwa etika bisnis adalah proses dan upaya untuk mengetahui hal-hal yang benar dan yang salah di tempat kerja, dan melakukan hal-hal yang benar berkenaan dengan produk dan pelayanan perusahaan, serta dalam hubungannya dengan pihak-pihak (pribadi dan kelompok) yang memiliki kepentingan atau tuntutan terhadap perusahaan (stakeholders). Intinya adalah bagaimana upaya semua pihak untuk mengetahui dan melakukan atau mempraktikkan sistem nilai yang dianut secara konsekuen.

Banyak faktor yang turut mempengaruhi etika bisnis ini, terutama dari dalam perusahaan. Faktor dari dalam berkaitan dengan integritas pemimpin dalam hal ini para direksi dalam membangun nilai-nilai yang bisa diikuti oleh semua elemen dalam perusahaan menjadi hal yang sangat penting dalam membangun keteladanan. Tan Lay Hong, et al., ${ }^{25}$ menyatakan sebagai berikut:

\footnotetext{
${ }^{20}$ Ibid., hal. 126.

${ }^{21}$ Nindyo Pramono, "Bunga Rampai Hukum Bisnis Aktual”, (Bandung: Citra Aditya Bakti, 2006), hal. 36.

${ }^{22}$ Ibid. hal. 37.

${ }^{23}$ Pasal 1 ayat (1) Undang-Undang Nomor 8 Tahun 1997 tentang Dokumen Perusahaan.

${ }^{24}$ Paripurna P. Sugarda, Pengelolaan Perusahaan Yang Baik: Apakah Hanya Etika Bisnis Atau Juga Persyaratan Hukum?, “Jurnal Hukum Bisnis”, Vol. 14, Juli 2001, hal. 55.

${ }^{25}$ Tan Lay Hong, Tan Chong Huat and Long Hsueh Ching, "Corporate Governance of Listed Companies in Singapore”, (Singapore: Sweet \& Maxwell Asia, 2006), hal. 253.
} 
Corporate ethics, in the broad sense, encompass aspects such as corporate leadership and integrity, corporate social responsibility, and the establishment of an open culture with embedded core values internalized and enfoced uniformly from the board of directors to the rank and file.

Richard T. De George sebagaimana dikutip Sony Keraf ${ }^{26}$ menyatakan bahwa jika setiap orang yang terlibat dalam bisnis atau perusahaan (pembeli, penjual, produsen, manajer, karyawan dan konsumen) bertindak tanpa memperdulikan moral maka lambat laun bisnis tersebut akan segera mati. Senada dengan itu, Tom Morris, sebagaimana dikutip Oscar Wirawan ${ }^{27}$ menyebutkan bahwa moralitas dalam wujud kepercayaan itu, seperti pelumas dalam hubungan antara manusia. Tanpa kepercayaan mekanisme interaksi antar manusia akan rusak dan berhenti. Satu-satunya cara yang sangat bijaksana dalam menjalankan sebuah bisnis atau perusahaan adalah meminta dengan sangat kepada semua orang yang terlibat agar mereka selalu berbicara jujur, kepada sesama karyawan, pemasok, pelanggan maupun pemerintah. Kebenaran harus menjadi nilai pembimbing setiap organisasi yang menghargai kelangsungan hidupnya sendiri. Tidak ada landasan yang lebih kokoh selain kebenaran untuk mendapatkan keunggulan berkesinambungan. Berdasarkan konsep etika bisnis yang telah dipaparkan diatas dapat disimpulkan bahwa etika bisnis adalah sistem nilai yang berlaku dalam masyarakat bisnis.

A. Sony Keraf, ${ }^{28}$ menyebutkan ada lima prinsip etika bisnis yakni: prinsip otonomi, kejujuran, keadilan, saling menguntungkan, dan integritas moral. Kelima prinsip tersebut bersumber dari satu prinsip utama/pokok atau golden rule yakni prinsip no harm (prinsip tidak merugikan hak dan kepentingan orang lain). Sebagai sebuah prinsip utama atau pokok, prinsip no harm ini pada tingkatan tertentu terkandung prinsip etika bisnis lainnya. Nilainilai yang terkandung dalam prinsip no harm sudah dengan sendirinya tercakup prinsip kejujuran, saling menguntungkan, otonomi (termasuk kebebasan dan tanggung jawab), dan integritas moral. Orang yang jujur dengan sendirinya tidak akan merugikan orang lain; orang yang mau saling menguntungkan dengan pihak lain tentu tidak akan merugikan pihak lain; dan demikian orang yang otonom dan bertanggung jawab tidak akan mau merugikan orang lain tanpa alasan yang dapat diterima dan masuk akal.

${ }^{26}$ A. Sony Keraf, Op. Cit., hal. 59. Lihat juga Richard T. De George, "Business Ethics”, (New York: MacMillan Publishing, 1986), hal. 9.

27 Pendapat Tom Morris tersebut dikutip oleh Oscar Wirawan dalam High Trust Business; Mengenal Hubungan Etika dan Keunggulan, "Majalah Intra”, Edisi 03/Vol. III September 2004, hal. 36.

${ }^{28}$ A. Sony Keraf, Ibid., hal. 74-79. K. Bertens menyebut ada enam prinsip etika bisnis yang harus diperhatikan oleh pelaku bisnis. Prinsip tersebut adalah: prinsip otonomi, kejujuran, keadilan, saling menguntungkan, integritas moral dan no harm. Apa yang diuraiankan Bertens pada hakikatnya tidak jauh berbeda dengan uraian Sony Keraf. Hanya saja Sony Keraf menyebutkan prinsip no harm ini sebagai the golden rule (kaidah emas), sedangkan Bertens menyebutkan prinsip no harm hanya sebagai salah satu prinsip dari keenam prinsip etika bisnis pada umumnya. 


\section{Etika Bisnis dan Hukum}

Steiner sebagaimana dikutip Paripurna P. Sugarda ${ }^{29}$ menjelaskan hubungan antara etika dengan hukum sebagai berikut:

Law codify ethical expectation and change overtime as a new evil. But law cannot cover all ethical expectations of society; they simply cannot blanket every area of conduct. Law is reactive; New status and enforcement always lag behind the opportunity for corporate expediency.

Apa yang diuraikan oleh Steiner ini dapat dimaknai bahwa hukum memang mengkodifikasi nilai-nilai etis yang terkandung dalam etika, namun harus disadari bahwa tidak semua hal yang ada dalam area etika di-cover oleh hukum. Memang harus diakui bahwa etika dan hukum memiliki dimensi yang berbeda dalam pengaturannya. Artinya bahwa tidak semua hal diatur oleh hukum karena ada hal-hal tertentu yang tetap menjadi domain dari etika.

Hubungan antara etika dengan hukum digambarkan oleh John Farar sebagai berikut:

...It refers to the companies legislation but it also transcends the law because we are looking not only at legal control but also de facto control of corporations. In addition, we are also looking at accountability, not only in terms of legal restraints but also in terms of systems of self-regulation and the norms of so-called 'best practice'. Self-regulation starts off a simple concept but becomes progressively more complex. Added to this we have business ethics. ${ }^{30}$

Farrar $^{31}$ selanjutnya menegaskan bahwa ada empat komponen penting dari good corporate governance yakni: business ethics, code of conduct guidelines statements of best practice, stock exchange listing requirements and statements of accounting practice dan legal regulation. Apa yang diuraikan oleh Farar dan Steiner menegaskan bahwa baik etika bisnis maupun hukum, masing-masing memiliki ruang lingkup yang saling melengkapi satu dengan yang lainnya, tidak bisa diutamakan yang satu dan mengabaikan yang lainnya.

Menurut Murphy dan Coleman sebagaimana dikutip Andre Ata Ujan $^{32}$ menyebutkan bahwa hubungan antara hukum dan moralitas (etika bisnis) hanya berbeda dari dari sisi formal, tetapi tidak ada perbedaan

${ }^{29}$ Paripurna, Op. Cit., hal. 55.

30 John Farrar, “Corporate Governance, Theories, Principles and Practice”, (Oxford University, 2008), hal. 4.

${ }^{31}$ Ibid.

32 Andre Ata Ujan, "Membangun Hukum, Membela Keadilan Filsafat Hukum”, (Yogyakarta: Kanisius, 2009), hal. 153. 
mendasar dari segi substansi. Baik norma hukum maupun norma moral, keduanya sama-sama mengatur prilaku manusia. Keduanya memberi batasan dalam bentuk perintah dan larangan mengenai apa yang seharusnya dilakukan dan tidak seharusnya dilakukan.

Menurut teori hukum kodrat, hukum dan moralitas tidak dapat dipisahkan. Hukum dan moralitas keduanya ditemukan dalam setiap masyarakat dan berfungsi mengatur prilaku masyarakat meskipun dengan kekuatan mengikat berbeda. Hubungan antara hukum dan moralitas tersebut oleh H.L.A. Hart dinyatakan sebagai berikut:

..., It cannot seriously be disputed that the development of law, at all time and place, has in fact been profoundly influenced both by the conventional morality and ideals of particular social groups, and also by forms of enlightened moral criticism urged by individuals, whose moral horizon has transcended the morality currently accepted. But it is possible to take truth illicitly, as warrant for a different proposition: namely that a legal system must exhibit some specific conformity with morality or justice, or must rest on a widely diffused confliction that there is a moral obligation to obey it. ${ }^{33}$

Etika dapat dipandang sebagai state of the art hukum, yakni pedoman prilaku hari ini ditafsirkan ke dalam hukum, peraturan, dan pedoman di kemudian hari. Norma dan aturan tersebut kemudian diwujudkan dalam bentuk hukum. Hukum mengkodifikasi harapanharapan etika, meskipun disadari bahwa tidak semua harapan etika tersebut dapat dipenuhi oleh hukum. Norma memang bersifat dinamis tetapi begitu ia dituangkan dalam hukum, sifat dinamisnya menjadi berkurang dan bahkan mungkin menjadi bersifat statis. Jelas disini bahwa keberadaan etika bisnis tidak dapat digantikan oleh hukum. ${ }^{34}$ Itu sebabnya ada bagian dari good corporate governance yang tetap merupakan bagian etika bisnis dan pada bagian tertentu merupakan domain dari hukum. Pembentukan, perumusan, dan penerapan suatu etika bisnis tergantung kondisi lingkungan bisnis, sedangkan hukum tergantung dari sumber-sumber hukum formil ${ }^{35}$ yang mengakui eksistensi prinsip good corporate governance sebagai bagian dari hukum tersebut. Jika penyimpangan-penyimpangan etika bisnis yang sudah sedemikian sulit diatasi (moral anarchy), maka hukum dalam hal ini menjadi sarana yang tepat untuk mendorong ditaatinya nilai-nilai etis tersebut.

Kadang ada yang berpendapat bahwa etika bisnis masih merupakan opini tentang sesuatu yang tidak dapat didiskusikan secara rasional. Pendapat tersebut kurang tepat. Permasalahannya tidak terletak pada

\footnotetext{
${ }^{33}$ H.L.A. Hart, “The Concept of Law”, (Clarendon, Oxford, 1961), hal.181.

${ }^{34}$ Paripurna, Op. Cit., hal. 60.

${ }^{35}$ Sumber hukum formil adalah: undang-undang, kebiasaan dan adat, perjanjian internasional, putusan pengadilan (yurisprudensi) dan doktrin atau pendapat para ahli hukum.
} 
kenyataan bahwa etika bisnis tidak dapat dipaksakan berlakunya. Etika bisnis dapat dipaksakan berlakunya oleh bisnis yang memilih untuk menerima prosedur untuk membuat etika bisnis berlaku. Kesukarannya terletak pada kenyataan bahwa norma bisnis tidak diberikan oleh sumbersumber eksternal. Etika bisnis mencerminkan kepentingan-kepentingan yang berbenturan (conflicting of interest) dari konstituen bisnis, dan harus dibuat secara pasti serta dapat dilaksanakan untuk dapat digunakan dalam pelbagai bentuk dan situasi bisnis yang berbeda. ${ }^{36}$

Memang disadari tidaklah mudah memecahkan ketidakpastian dan problem pemberlakuan etika bisnis. Apa yang dikatakan adil pada perusahaan yang satu tidaklah selalu sama di perusahaan lainnya. Pemecahan masalah ini akan tergantung dari prosedur dalam perusahaan, yakni dengan dibentuknya suatu komite etika perusahaan yang akan bekerja mengembangkan aturan-aturan yang cukup jelas dalam suasana demokratis untuk kepentingan perusahaan yang disebut sebagai kode etik. $^{37}$

\section{Kode Etik}

Tan Lay Hong, et al. ${ }^{38}$ menyebutkan bahwa:

A code of ethics sets out a framework of fundamental principles which encompass operational requirements and prohibitions based on guiding values and formulation of behavioural standards by the leaders at the helm of a company.

Kode etik dalam tingkah laku berbisnis di perusahaan atau CCBC merupakan bagian penting dari kerangka kerja (framework) good corporate governance dan memberikan acuan dalam merumuskan kebijakan (policy), sistem dan prosedur (sisdur), atau instruksi kerja (work instruction). Kode etika (CCBC) menuntut karyawan dan pimpinan perusahaan untuk melakukan praktik-praktik etik bisnis yang terbaik di dalam semua hal yang dilaksanakan atas nama perusahaan.

Kode etik dapat ditetapkan sebagai pedoman bagi seluruh karyawan dan pimpinan perusahaan serta dapat diterbitkan dalam semacam "buku saku" agar mudah diperlajari dan dijadikan referesi. Apabila prinsip tersebut telah mengakar di dalam budaya perusahaan (corporate culture), maka seluruh karyawan dan pimpinan perusahaan akan berusaha untuk memahami dan mematuhi mana yang boleh dan mana yang tidak boleh dilakukan dalam aktivitas bisnis perusahaan. Kode etik merupakan implementasi dari salah satu prinsip good corporate governance. Implementasi good corporate governance di perusahaan memerlukan komitmen yang tinggi dari segenap karyawan dan pimpinan perusahaan.

\footnotetext{
${ }^{36}$ Paripurna, Op. Cit., hal. 55.

${ }^{37}$ Ibid.

${ }^{38}$ Tan Lay Hong, Tan Chong Huat and Long Hsueh Ching, Op. Cit., hal. 225.
} 
Salah satu prasyarat untuk mendapatkan standar good corporate governance yang tinggi adalah adanya kode etik yang menjadi pedoman prilaku sehari-hari dalam melaksanakan tugasnya. Setiap karyawan dan pimpinan perusahaan harus bertanggung jawab dan berusaha mematuhi kode etik. ${ }^{39}$

Kepatuhan pada kode etik ini merupakan hal yang sangat penting untuk mempertahankan dan memajukan reputasi perusahaan sebagai karyawan dan pimpinan perusahaan yang bertanggung jawab, dimana pada akhirnya akan memaksimalkan nilai pemegang saham (shareholder value). Beberapa nilai etika perusahaan yang sesuai dengan prinsip good corporate governance yaitu disiplin, kejujuran, tanggung jawab, saling percaya, keterbukaan dan kerja sama. Kode etik yang efektif seharusnya bukan sekedar buku atau dokumen yang tersimpan saja. Kode etik hendaknya dimengerti oleh seluruh karyawan dan pimpinan perusahaan yang pada akhirnya dapat dilaksanakan dalam bentuk tindakan nyata (action).

O.P. Simorangkir ${ }^{40}$ menyatakan bahwa adalah tidak tepat jika fokus dari kode etik berupa dibuatnya peraturan-peraturan yang dititikberatkan kepada sanksi bagi mereka yang melanggar etika tersebut. Pendapat tersebut dilandasi oleh pemikiran bahwa justru kode etik tujuannya adalah bagaimana nilai-nilai etis itu dapat tumbuh dan hidup dengan baik dalam sebuah komunitas meskipun kode etik tidak mencantumkan sanksi hukum bagi yang melanggarnya. Artinya bahwa sanksi hukum bukanlah tujuan dibuatnya kode etik tersebut. Kode etik adalah persetujuan bersama yang timbul dari para anggota itu sendiri untuk lebih mengarahkan perkembangan mereka, sesuai dengan nilai-nilai ideal yang diharapkan. Jadi kode etik adalah hasil murni yang sesuai dengan aspirasi profesi suatu kelompok tertentu, demi untuk kepentingan bersama dan kerukunan.

Pendapat lainnya dikemukakan Muh. Arief Effendi ${ }^{41}$ dengan menyatakan bahwa pelanggaran atas kode etik adalah hal yang serius, bahkan dapat dikategorikan pelanggaran hukum. Oleh karena itu, pelanggaran terhadap kode etik harus mendapatkan sanksi (punishment) sesuai ketentuan yang berlaku, bahkan dapat menimbulkan pemutusan hubungan kerja (PHK). Beberapa tindakan karyawan dan pimpinan perusahaan yang termasuk kategori pelanggaran terhadap kode etik antara lain mendapatkan, menggunakan, atau menyalahgunakan aset milik perusahaan untuk kepentingan atau keuntungan pribadi secara phisik mengubah atau merusak aset milik perusahaan tanpa izin yang sesuai dan menghilangkan aset milik perusahaan. Untuk melakukan pengujian atas kepatuhan terhadap kode etik tersebut perlu dilakukan

${ }^{39}$ Muh. Arief Effendi, Op. Cit., hal. 123.

${ }^{40}$ O.P. Simorangkir, “Etika: Bisnis, Jabatan, dan Perbankan”, (Jakarta: Rineka Cipta, 2003), hal. 87.

\footnotetext{
${ }^{41}$ Muh. Arief Effendi, Op. Cit., hal. 123.
} 
semacam audit kepatuhan (compliance audit) oleh pihak yang independen, misalnya auditor internal sehingga dapat diketahui adanya pelanggaran berikut sanksi yang akan dikenakan terhadap karyawan dan pimpinan perusahaan yang melanggar kode etik dimaksud.

Menyikapai kedua pandangan tersebut, Penulis berpendapat bahwa kepatuhan terhadap kode etik adalah hal yang mutlak karena itu menjadi tujuan dibuatnya kode etik tersebut. Pertanyaannya adalah bagaimana caranya agar kode etik tersebut dipatuhi oleh semua elemen dalam perusahaan itu? Itu sebabnya peran dari otoritas yang berwewenang dalam hal ini pimpinan perusahaan dalam menerapkan strategi manajemen berupa pembinaan dan pengawasan yang bersifat etis sehingga terbangunnya kesadaran etis dalam mematuhi kode etik. Pendekatan pembinaan dan pengayoman terhadap nilai-nilai etis harus menjadi prioritas utama dalam penerapan kode etik. Tujuan dari kode etik adalah bagaimana membangun kesadaran etis agar dapat tumbuh dan berkembang dan pada akhirnya menjadi gaya hidup bagi setiap pemimpin dan karyawan perusahaan. Hal itu tidak berarti bahwa sanksi terhadap mereka yang melanggar ketentuan kode etik tidak diperbolehkan. Artinya bahwa sanksi berupa tindakan tegas kepada mereka yang melanggar adalah sebuah keniscayaan manakala didahului dengan pembinaan dan pengayoman nilai-nilai etis terlebih dahulu.

\section{Budaya Perusahaan}

Pada dasarnya budaya perusahaan (corporate culture) itu tidak lain adalah budaya organisasi yang berlaku di sebuah perusahaan. Budaya perusahaan atau oleh Sony Keraf disebut etos bisnis adalah suatu kebiasaan atau budaya moral menyangkut kegiatan bisnis yang dianut dalam suatu perusahaan dari satu generasi ke generasi yang lain. Inti etos ini adalah pemberdayaan atau pembiasaan penghayatan akan nilai, norma, atau prinsip moral tertentu yang dianggap sebagai inti kekuatan dari suatu perusahaan yang sekaligus juga membedakannya dari perusahaan lain. Wujudnya bisa dalam bentuk pengutamaan mutu, pelayanan, disiplin, kejujuran, tanggung jawab, perlakuan yang fair tanpa diskriminasi, dan seterusnya. ${ }^{42}$

Menurut Daniel R. Denison, ${ }^{43}$ budaya perusahaan adalah variabelvariabel perilaku yang mengacu pada nilai keyakinan dan prinsip-prinsip yang ada sebagai dasar untuk mengelola perusahaan. Prinsip dasar tersebut akan diperjelas dan didukung oleh praktik manajemen dan perilaku dari seluruh komponen perusahaan. Budaya perusahaan, dengan demikian mempunyai pengaruh terhadap keefektifan suatu organisasi. Budaya perusahaan dapat dilihat dari aspek rasa keterlibatan

\footnotetext{
${ }^{42}$ A. Sony Keraf, Op. Cit., h. 81.

${ }^{43}$ Daniel R. Denison, "Corporate Culture and Organizational Effectiveness, (New York: John Willey \& Son, 1990), hal. 2-4.
} 
(involvement), konsistensi (consistency), adaptabilitas (adaptability), dan misi (mission).

Budaya perusahaan adalah kumpulan nilai-nilai (values) dan unsurunsur yang menentukan identitas dan perilaku suatu organisasi perusahaan. Sukses atau tidaknya suatu perusahaan dalam menjalankan bisnisnya memang tidak terlepas dari budaya perusahaan yang dimilikinya. Oleh karena itu, budaya perusahaan perlu diaktualisasikan melalui penyusunan pedoman kebijakan (policy guidelines) sehingga diharapkan dapat memaksimalkan kontribusi seluruh karyawan dan pimpinan perusahaan dalam mewujudkan visi dan misi perusahaan. Budaya perusahaan merupakan hasil penggalian dari perjalanan panjang suatu perusahaan dalam menghadapi lingkungan (environtment) yang terus berubah (turbulence) dan dikritalisaikan serta dirumuskan dengan dirangsang oleh berbagai inspirasi dari perusahaan lain dan berbagai tantangan dari luar. ${ }^{44}$

Berikut ini merupakan pengertian nilai-nilai budaya yang dipraktikkan oleh perusahaan: ${ }^{45}$ Pertama adalah kerja keras. Nilai kerja keras adalah suatu usaha yang sungguh-sungguh tanpa melakukan penundaan waktu, artinya pekerjaan yang bisa diselesaikan pada hari ini, akan diselesaikan hari ini juga. Kerja keras juga bermakna bahwa pekerjaan dilakukan dengan berkonsentrasi penuh sehingga bisa terhindar dari pemborosan (ineficiency), baik waktu, tenaga, maupun biaya. Kerja keras memerlukan rasa percaya diri yang tinggi sehingga tidak cepat putus asa dan selalu memiliki semangat pantang menyerah.

Kedua adalah disiplin. Nilai disiplin tidak hanya ditunjukkan datang tepat waktu (on time) atau tidak terlambat, namun juga berarti menepati acara-acara rapat. Disiplin memiliki arti menepati janji yang telah disanggupi, menepati kesepakatan bersama, serta dapat dijadikan teladan yang baik. Disiplin juga bermakna ketaatan (compliance) terhadap peraturan perundang-undangan serta prosedur yang berlaku dan telah ditetapkan oleh perusahaan. Kultur disiplin (culture of discipline) mengandung 3 (tiga) hal berikut ini, yakni disciplined people (no need of hierarchy); disciplined thought (no need of bureaucracy); disciplined action (no need of excessive controls).

Ketiga adalah integritas. Nilai integritas ini ditunjukkan dari sikap yang secara konsisten menunjukkan kejujuran, kesesuaian antara perkataan dan tindakan, serta penuh rasa tanggung jawab terhadap pengelolaan perusahaan. Keempat adalah pembelajar. Nilai pembelajar ditunjukkan dari sikap selalu mengikuti perkembangan ilmu pengetahuan dan teknologi serta bersedia menjalani pendidikan profesi berkelanjutan (PPL) sesuai bidang masingmasing. Seseorang yang termasuk pembelajar biasanya memiliki rasa ingin tahu yang tinggi, bersedia berbagi (knowledge sharing) dan berbagi

\footnotetext{
${ }^{44}$ Muh. Arief Effendi, Op. Cit., hal. 117.

${ }^{45}$ Ibid., hal.120.
} 
pengalaman (experience sharing), serta menghargai pemikiran (ide) baru dan hasil karya yang inovatif.

Kelima adalah kerja sama. Nilai kerja sama ditunjukkan dengan kesediaan untuk memberi dan menerima kontribusi dari dan/atau kepada sesama karyawan, atasan, atau pihak lain yang terkait untuk mencapai visi dan misi perusahaan. Keenam adalah saling menghargai. Nilai saling menghargai ditunjukkan dengan penghargaan terhadap individu, tugas dan tanggung jawab pihak lain. Ketujuh adalah inovatif. Nilai inovatif ditunjukkan dengan penuh gagasan (kreatif), aktif dan menyukai tantangan. Kedelapan adalah terampil. Nilai terampil ditunjukkan menguasai pekerjaan, cepat, tanggap dan akurat. Kesembilan adalah bersih. Nilai bersih (clean) ditunjukkan dengan transparan dalam pengelolaan dan terpercaya di mata masyarakat dan stakeholders lainnya.

Djoko Santoso Moeljono menyebutkan bahwa sebelum suatu perusahaan menerapkan good corporate governance sebaiknya perusahaan tersebut menerapkan terlebih dahulu nilai-nilai yang terkandung dalam budaya perusahaan (corporate culture) yang dianutnya. Good corporate governance dapat berjalan apabila individu-individu dalam perusahaan secara internal mempunyai sistem nilai (value system) yang mendorong mereka untuk menerima, mendukung dan melaksanakan good corporate governance. Sistem nilai yang ada pada individu, tumbuh di dalam perusahaan dan digunakan sebagai sistem perekat ini disebut sebagai corporate culture. Hal tersebut terbukti dengan keberhasilan beberapa perusahaan kelas dunia (world class company) maupun perusahaan multinasional dalam menerapkan good corporate governance setelah terlebih dahulu menjalankan budaya perusahaan dengan konsisten. ${ }^{46}$ Itu sebabnya dapat dikatakan bahwa hubungan antara good corporate governance dengan budaya perusahaan selalu berbading lurus. Implementasi good corporate governance di perusahaan dapat berhasil dengan baik atau sukses apabila didukung dengan internalisasi budaya perusahaan yang baik. Tanpa budaya perusahaan yang kuat dan dijalankan dengan konsisten, maka implementasi good corporate governance akan mengalami kesulitan bahkan bisa mengalami kegagalan. ${ }^{47}$

Teddy P. Rahmat saat menjabat sebagai CEO di Astra International pada awal tahun 1980-an, pernah mengatakan bahwa esensi budaya perusahaan adalah kepemimpinan. Pendapat tersebut dilandasi pemikiran bahwa peran pemimpin sangat penting dalam membangun nilai-nilai corporate culture pada perusahaan tersebut. Pada masa kepemimpinannya di PT Astra International, beliau adalah orang pertama yang mendorong dan menjalankan budaya dan tata nilai tersebut. Apa yang dilakukan tersebut, kini sudah menjadi gaya hidup bagi pimpinan dan karyawan Astra. Hal ini merupakan salah satu cara untk menciptakan budaya perusahaan yang sesuai sehingga dapat mendorong pengambilan keputusan serta mengendalikan tingkah laku dalam berbisnis. PT.

46 Djoko Santoso Moeljono, "Good Corporate Culture Sebagai Inti dari Good Corporate Governance”, Cetakan Kedua, (Jakarta: Elex Media Komputindo, 2006), hal. 8.

${ }^{47}$ Ibid. 
Timah yang awalnya hampir kolaps, dengan menjalankan budaya perusahaan secara konsisten, akhirnya bisa bangkit kembali menjadi perusahaan pertambangan kelas dunia (world class company). ${ }^{48}$

Joseph W. Weiss ${ }^{49}$ menyebutkan bahwa berhasil tidaknya pelaksanaan budaya perusahaan dalam sebuah perusahaan sangat ditentukan oleh gaya kepemimpinan dalam perusahaan itu. Betapapun baiknya nilai dan prinsip moral tertentu yang hendak diterapkan, apabila tidak ditunjang dengan gaya kepemimpinan yang kondusif untuk menumbuhkan budaya perusahaan yang baik, budaya perusahaan sulit akan berkembang di perusahaan tersebut. Gaya kepemimpinan manajer profesional yang menekankan kerjasama kelompok serta gaya kepemimpinan yang bersifat transformatif akan lebih kondusif bagi berkembangnya budaya perusahaan yang baik dalam suatu perusahaan. Gaya kepemimpinan yang bersifat manipulator atau administrator birokratis dalam banyak hal akan sulit menumbuhkan budaya perusahaan. Gaya kepemimpinan semacam itu terlalu memperalat karyawan demi tujuan perusahaan.

\section{Penutup}

Berdarkan uraian diatas dapat disimpulkan beberapa hal sebagai berikut:

1) Prinsip perlindungan terhadap investor obligasi dilihat dari aspek emiten obligasi adalah prinsip perlindungan hukum preventif. Dalam hal ini, emiten obligasi mengelola perusahaannya berlandaskan pada prinsip good corporate governance berupa penerapan etika bisnis. Penerapan etika bisnis secara konsisten berdampak terhadap kepercayaan publik. Kepercayaan publik tidak hanya mendatangkan profit bagi emiten tetapi juga berdampak positif terhadap efek yang diperdagangkan di pasar modal karena memberikan capital gain bagi pemegangnya.

2) Prinsip good corporate governance dapat berdimensi etika bisnis dan prinsip hukum bisnis. Meskipun kedua hal tersebut memiliki unsur pemaksa yang berbeda namun kedua hal tersebut berkontribusi positif bagi perusahaan. Dengan demikian etika bisnis adalah kewajiban etis yang harus dipatuhi oleh emiten obligasi.

3) Kemampuan suatu negara dalam menarik investasi asing masuk ke sebuah negara, sangat tergantung pada sistem corporate governance yang dianutnya. Ada dua aspek penting pokok dari good corporate governance adalah etika bisnis dan hukum. Para investor tidak bersedia menanamkan modalnya pada perusahaan di suatu negara yang tidak memiliki sistem corporate governance yang efektif. Dalam perspektif hukum bisnis, keberhasilan suatu perusahaan tidak cukup hanya diukur dari hasil kinerja keuangan dan peningkatan nilai pemegang saham

\footnotetext{
${ }^{48}$ Muh. Arief Effendi, Op. Cit., hal. 119.

49 Joseph W. Weiss, “Business Ethics: A Managerial, Stakeholder Approach”, (Belmont: Wadsworth Pub. Com., 1994), hal. 111.
} 
(share holders value) semata, tetapi orang mulai mengaitkannya dengan seberapa baik perusahaan telah menerapkan prinsip good corporate governance dengan baik. 


\section{Daftar Pustaka}

\section{Buku}

Ang, Robert. Buku Pintar Pasar Modal Indonesia, Jakarta: Mediasoft Indonesia, 1997.

Bertens, K. Pengantar Etika Bisnis, Yogyakarta: Kanisius, 2000.

Cahyana, Jaka E. Langkah Taktis Metodis Berinvestasi di Obligasi, Jakarta: Elex Media Komputindo, 2004.

Darmadji, Tjiptono dan Hendy Fakhruddin. Pasar Modal di Indonesia, Jakarta: Salemba Empat, 2001.

De George, Richard T. Business Ethics, New York: MacMillan Publishing, 1986.

Denison, Daniel R. Corporate Culture and Organizational Effectiveness, New York: John Willey \& Son, 1990.

Effendi, Muh. Arief. The Power of Good Corporate Governance Teori dan Implementasi, Jakarta: Salemba Empat, 2009.

Emirzon, Joni. Prinsip Good Corporate Governance: Paradigma Baru dalam Praktik Bisnis Indonesia, Yogyakarta: Genta Press, 2007.

Farrar, John. Corporate Governance, Theories, Principles and Practice, Oxford University, 2008.

Hart, H.L.A. The Concept of Law, Oxford: Clarendon, 1961.

Keraf, A. Sony. Etika Bisnis; Tuntutan dan Relevansinya, Yogyakarta: Kanisius, 1998.

Khairandy, Ridwan dan Camelia Malik. Good Corporate Governance Perkembangan Pemikiran dan Implementasinya di Indonesia dalam Perspektif Hukum, Yogyakarta: Kreasi Total Media, 2007.

Kretarto, Agus. Investor Relation: Pemasaran dan Komunikasi Keuangan Perusahaan Berbasis Kepatuhan, Jakarta: Grafiti Pers, 2001.

Moeljono, Djoko Santoso. Good Corporate Culture Sebagai Inti dari Good Corporate Governance, Cetakan Kedua, Jakarta: Elex Media Komputindo, 2006.

Morawetz, Thomas. The Philosophy of Law: An Introduction, New York: Macmillan Publishing, 1980

Pramono, Nindyo. Hukum PT Go Public dan Hukum Pasar Modal, Yogyakarta: Andi, 2013.

Bakti, 2006.

Bunga Rampai Hukum Bisnis Aktual, Bandung: Citra Aditya 
Rahardjo, Sapto. Panduan Investasi Obligasi, Jakarta: Gramedia Pustaka Utama, 2003

Silalahi, Gabriel Amin. Strategi Etika Bisnis dan Studi Kasus, Sidoarjo: Citra Media, 2003.

Sili, Eduardus Bayo. Prinsip Perlindungan Hukum Investor Obligasi, Disertasi, Program Studi Doktor Ilmu Hukum Universitas Airlangga, Surabaya, 2015.

Simorangkir, O.P. Etika: Bisnis, Jabatan, dan Perbankan, Jakarta: Rineka Cipta, 2003.

Sumantoro. Pengantar Tentang Pasar Modal di Indonesia, Jakarta: Ghalia Indonesia, 1990.

Surya, Indra dan Ivan Yustiavandana. Penerapan Good Corporate Governance Mengesampaingkan Hak-Hak Istimewa Demi Kelangsungan Usaha, Jakarta: Kencana, 2008.

Tan Lay Hong, Tan Chong Huat and Long Hsueh Ching. Corporate Governance of Listed Companies in Singapore, Singapore: Sweet \& Maxwell Asia, 2006.

Tjager, I Nyoman. et al. Corporate Governance: Tantangan dan Kesempatan bagi Komunitas Bisnis Indonesia, Jakarta: Prenhallindo, 2003.

Ujan, Andre Ata. Membangun Hukum, Membela Keadilan Filsafat Hukum, Yogyakarta: Kanisius, 2009.

Weiss, Joseph W. Business Ethics: A Managerial, Stakeholder Approach, Belmont: Wadsworth Pub. Com., 1994.

\section{Artikel:}

Sugarda, Paripurna P. "Pengelolaan Perusahaan Yang Baik: Apakah Hanya Etika Bisnis Atau Juga Persyaratan Hukum?", Jurnal Hukum Bisnis, Vol. 14, Juli 2001.

Wirawan, Oscar. dalam "High Trust Business; Mengenal Hubungan Etika dan Keunggulan”, Majalah Intra, Edisi 03/Vol. III September 2004.

\section{Peraturan:}

Undang-Undang Nomor 8 Tahun 1997 tentang Dokumen Perusahaan.

Undang-Undang Nomor 8 Tahun 1995 tentang Pasar Modal.

Peraturan Pemerintah Nomor 45 Tahun 1995 tentang Penyelenggaraan Kegiatan di Bidang Pasar Modal. 